\title{
SZÜKSÉGES...DE ELÉGSÉGES? A TÁRSADALMI INTEGRÁCIÓ MÉRÉSÉRŐL AZ EURÓPAI UNIÓBAN
}

Szerzők:

Gégény János

Debreceni Egyetem

Szerző e-mail címe:

gegenyjr@gmail.com
Lektorok:

Murányi István

Debreceni Egyetem

Mező Ferenc

Debreceni Egyetem

Szilágyi Barnabás

Debreceni Egyetem

Nemes Magdolna

Debreceni Egyetem

Gégény János (2016): Szükséges... De elégséges? A társadalmi integráció méréséről az Európai Unióban. Különleges Bánásmód, II. évf. 2016/4. szám, 5-17. DOI 10.18458/KB.2016.4.5

\begin{abstract}
Absztrakt
A tanulmány hivatalos Eurostat adatokat közöl a migrációs válság néven elhíresült eseménysorozatról illetve az Európai Unión kívülről az Európai Unióba érkező bevándorlók társadalmi integrációjának mérésére használt módszereket vizsgálja. Amellett érvelek, hogy a jelenleg használt ún. Zaragoza indikátorok nem képesek a harmadik országbeli bevándorlók társadalmi integrációs folyamatának minden aspektusát lefedni, így képtelenek megfelelően átfogó képet biztosítani a szakemberek és a döntéshozók számára. Ennek alátámasztására egy kísérletben hat országra vonatkozóan (Egyesült Királyság, Németország, Hollandia, Franciaország, Belgium, Svájc ) ötvözöm a Zaragoza indikátorok valamint az EurIslam kutatás eredményeit. Az EurIslam egy európai muszlimok és többségi társadalmak viszonyait vizsgáló kutatás, melynek megfontolásai lehetőséget kínálnak a társadalmi integráció mérésére használt indikátorok kibővítésére.
\end{abstract}

Kulcsszavak: Migrációs válság, Társadalmi Integráció, Zaragoza, EurIslam

Diszciplina: szociológia

\section{Abstract \\ NECESSARY... BUT SUFFICIENT? \\ ABOUT MEASURMENT OF SOCIAL INTEGRATION IN THE EUROPEAN UNION}

This paper reports official data about the well known EU migration crisis and examines the methods used to evaluate the social integration of third country migrants into the European Union. I argue that the Zaragoza indicators, - which are currently being used - cannot include all the aspects of migrant integration, and because of this deficiency, they are not able to track the ongoing integrational processes correctly for experts and decision makers. To demonstrate 
and prove this argument a comparative analysis is performed in the article. I compare data about six countries (United Kingdom, Germany, The Netherlands, France, Belgium and Switzerland) from two data sources: the Zaragoza Indicators and the EurIslam research. The EurIslam research is a complex social-scientific project for examining the relation between Muslim migrants and their host societies and its overall considerations could make the future extension of Zaragoza indicators possible.

Keywords: Migration crisis, Social Integration, Zaragoza, EurIslam

Discipline: sociology

Az Európai Unió útját az elmúlt tíz évben több válság kísérte. Alig sikerült a 2008-as, az EU történetének eddigi legnagyobb, világszintü pénzügyi válságból kilábalni, 2015-ben egy újabb, a köztudatban szintén válságként jelen lévő eseménysorozat gyakorolt hatást az Eu-ra és az egész világra. Arról a migrációs válság néven elhíresült és hivatkozott, hosszú hónapokon át zajló folyamatról van szó, ami drámai módon, félelmetesen emberi és embertelen következményeivel világított rá a Közös Migrációs és Menekültügyi Politika, a Közös Kül- és Biztonságpolitika valamint az EU tagállamok egységes fellépésének és a tagállamok közötti együttmüködésnek a hiányosságaira. Ennek a történelmi jelentőségü eseménysorozatnak olyan hosszútávú hatásai lehetnek, amelyek elörejelzéséhez, okainak megértéséhez és kezeléséhez széleskörü tudományközi összefogásra van szükség. Az ehhez vezető kezdő lépések egyikét tette meg az a társaság, amelynek tagjai a Debreceni Egyetem Tehetséggondozó Program (DETEP) Dr. Mező Ferenc által vezetett Interdiszciplináris Kutatócsoportján belül, a téma egyenként minél specifikusabb, és együtt minél teljesebb körü megértésére vállalkoztak. Ennek a társaságnak a tagjaként kérdőjelek sorával találtuk szemben magunkat, amelyek mögött olyan megoldandó rejtélyek sorakoztak, mint: „Hogyan folytatódik a menekültek élete az EU-ba érkezés után?” „Elérhetö-e és hogyan érhető el, hogy szerves és értékes tagjai lehessenek az európai társadalmaknak?” „Milyen intézkedéseket, terheket, tevékenységeket jelent ez a befogadó államok számára, valamint milyen lehetőségekkel és kötelezettségekkel jár az integrálódni vágyók számára?” Az első néhány kérdésre való elméleti, a szakirodalmak és a témában jártasak segítségével történő válaszgenerálás után egyetlen kérdöjel köré csoportosultak a fennmaradó nehezen megválaszolható kérdések, amelyek kettős-közös nevezője a „társadalmi integráció” kifejezés és a „hogyan” kérdőszó. Rendezve a képletet, a generált válaszok behelyettesítése és az azonos tagokkal történő egyszerüsítés után az egy ismeretlenessé alakított egyenletböl megszületett a jelen tanulmány fő kérdése: Hogyan mérhető a társadalmi integráció? A következőkben erre a kérdésre keressük a választ, kezdve az integráció fogalmát övező meggondolásokkal, folytatva az EU-ban használt mérési módszerek, és fö mutatók körüljárásával, egészen az azok vizsgálatával felfedezett néhány hiányosságig, és kiegészítésükre tett javaslatokig. Mielőtt azonban bejárnánk a ezt az utat, érdemes megvizsgálnunk a migrációs válságról elérhető hivatalos Eurostat és Frontex adatokat.

\section{Néhány adat a migrációs válságról}

Kutatómunkánk során általában véve is törkednünk kell a megbízható ésé révényes vizsgálatok végzésére: a felhasznált adatoknak minden esetben megbízhatónak és érvényesnek kell lenniük. A megbízható adat fogalma a legegyszerübben annyit jelent, hogy az adatoknak a lehető legközelebb kell állniuk a valósághoz, úgy, hogy akárhányszor támaszkodom rájuk, mindig megfelelően közel kell legyenek hozzá (Babbie, 2003; Drost, 2011). Az érvényes adat fogalma emellett annyit jelent, hogy az adatoknak arra az aktuális 
dologra kell vonatkozniuk, amit éppen vizsgálok (Babbie, 2003; Drost, 2011). Az Eurostat és a Frontex hivatalos adatai, szemben a számtalan különböző alapú és indíttatású, változatos lelőhelyeken előforduló becsült adatoktól, mindkét követelménynek eleget tesznek. A források és adataik felhasználhatósági kritériumai után nézzük meg, mit mondanak a hiteles, hivatalos adatok a migrációs válságról.

Az Unióba érkező menekültek száma 2010 Júniusa óta egészen tavaly októberig eltérő ütemben, de folyamatosan növekedett. A növekedés üteme 2014 nyarán kezdett az addigi legnagyobb mértékben gyorsulni, 2015-ben pedig az átlagos havi menedékkérők száma az öt évvel korábbi érték négyszeresére nőtt (1. ábra). A menekültáradat tetőpontja tavaly októberben volt, ekkor a 2010-es átlagos havi értékek közel nyolcszorosának megfelelö mennyiségü (185 340 darab) menedékkérelmet nyújtottak be. A hivatalos adatok a menekültkérelmek számát jegyzik, mivel az EU-n kívülről, harmadik országból érkező személyek csak útlevéllel látogathatják az EU tagállamok országait. Az útlevél hiánya ugyan nem feltétele a menedékkérelem benyújtásának, de útlevél nélkül, hosszabb távon csak menedékkérők tartózkodhatnak az EU területén.

1. ábra: Az átlagos, egy hónapra jutó és az összes menedékkérelem száma évente. Forrás: Eurostat és Frontex adatok alapján saját szerkesztés.

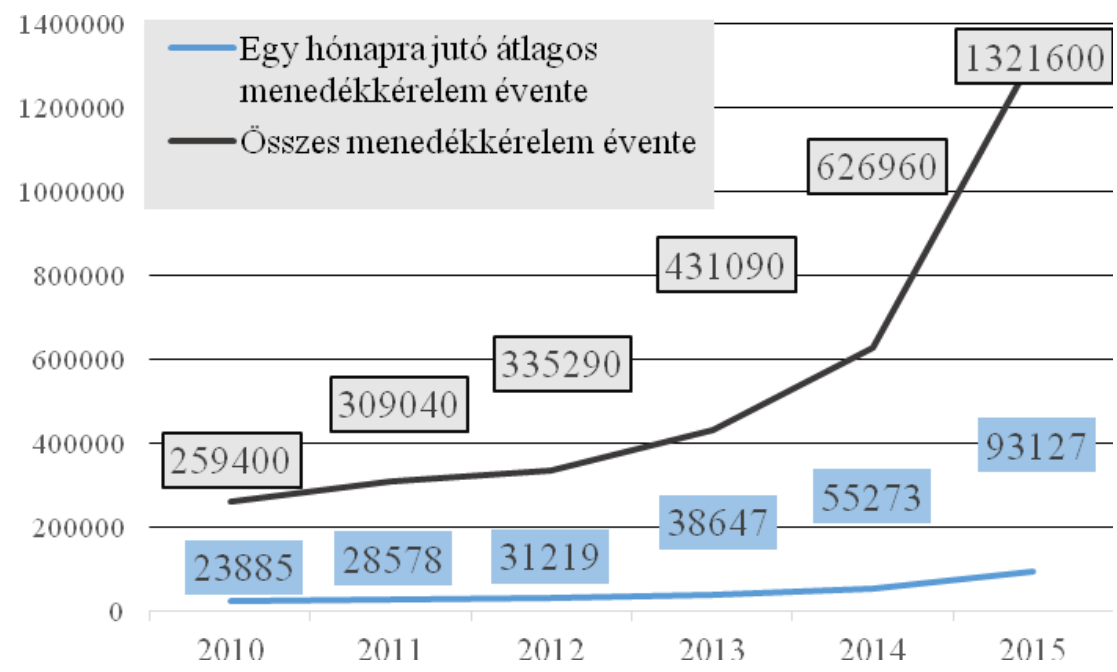

2015-ben összesen 1321600 menedékkérelmet regisztráltak, ami az EU össznépességének mindössze 0,26\%-a, de ha a 28 akkori tagállami helyett a menekültek hét fö célországának (Németország, Svédország, Franciaország, Hollandia, Svájc, Egyesült Királyság, Olaszország) össznépességégéhez viszonyítunk, akkor is csak 1 százalék. Ha a 2010 és 2015 között regisztrált összes menedékkérelem arányát vizsgáljuk az előbbi populációkban, a kapott eredmények, még mindig mindössze $1 \%$ és $2 \%$.

Ha a menekülteket az összes harmadik országból érkezett bevándorlóval együtt vizsgáljuk, az így kialakított csoport aránya az EU össznépességében akkor sem több, mint 4\%, a 2015ben érkező menekültek hét fő célországának népességében pedig 13\%. Jogosan merülhet fel a kérdés: „de mi a helyzet az illegálisan az EU-ban tartózkodókkal?” Pontos, hivatalos adatok nem ismertek, de az ábrákon lévő értékeken az illetékes hatóságok munkájának hála lényegesen nem változtatna. Ezen kívül az ábrákhoz használt, az összes 2010 és 2015 közötti 
menedékkérő számát jelző érték, a 2015-ben érkező összes, illegálisan az EU-ban tartózkodók számához képest nagy valószínüséggel jókora fölébecslést jelent.

Az Európába érkező menekültek megérkezésük után röviddel egy teljesen új, a korábban megszokottól eltérő környezettel, kulturális és szokásrendszerrel találkoznak, amelyekhez alkalmazkodniuk kell. Ehhez kínálnak segítséget a különböző integrációs politikák és tagállami gyakorlatok, amiket közös EU alapvetések füznek össze (EMN 2014; European Commission 2011). Ezek az alapok mind az integráció, a kölcsönös alkalmazkodás gondolata körül csoportosulnak és élesen szemben állnak egy másik elképzeléssel, az egyoldalú alkalmazkodást jelentő asszimilációval. Ebben a tanulmányban, az európai gyakorlattal összhangban, szintén az előbbiben gondolkodunk. Érdekes lehetne egy összehasonlítást készíteni az asszimiláció fogalmában gondolkodó, pl egyesült államokbeli szakirodalmak felhasználásával, de ettől a jelen tanulmányban eltekintünk. A következő lépés tehát az integráció, aminek tárgyalását a hozzá kapcsolódó fogalmi megfontolásokkal kell kezdenünk.

\section{Az integráció, mint fogalom}

$\mathrm{Az}$ integráció szó jelentését egyértelmüen, tartalmi összetettsége miatt nem egyszerü meghatározni. A kifejezés önmagában, korábban különálló részek egésszé történő összeállását, egységesülését jelenti (Juhász, 1989), azonban hétköznapi alakjában is több dolgot érthetünk alatta (Bocz, 2002). Használhatjuk gazdasági, regionális vagy éppen politikai értelemben, a következőkben azonban a társadalmi jelentéstartalomra fókuszálunk. A tartalmi szükítést követően a társadalmi integráció fogalma, még mindig többféleképpen értelmezhető, és értelmezett (Bocz, 2002). Kovách Imre szerint három jellegzetes formában fordul elő a kifejezés. Egyrészt társadalomelméleti, másrészt résztársadalmi csoportokra vonatkozó konkrét szociológiai vagy szakértői, és harmadrészt mindennapi laikus formájában. (Kovách és tsai, 2012). Ehhez hozzátehetjük, hogy (gyógy)pedagógiai kontextusban, a különleges bánásmódot igénylö gyermekek és tanulók esetében is alkalmazzuk az integráció kifejezést némileg más tartalommal, mint a társadalkmi integráció esetében. Az elméleti megközelítések között a társadalomtudományok és föként a szociológia olyan klasszikusainak az interpretációit találjuk, mint Durkheim, (1951) Weber (1995) vagy Parsons (1966), de a mai késő- vagy posztmodern elméletalkotók közül is többen Bourdieu (1994), Habermas (Mouzelis, 1992), Castells (1996) foglalkoztak már a témával. A társadalomelméleti fogalom teljesebb kibontása, és a kapcsolódó szociológiai elméletek bemutatása nélkül, a tanulmányban az előzőekben körülírt fogalomnak a szakpolitikai, Másként fogalmazva: gyakorlati, vagy konkrét szociológiai, változatát használom. Ebben az értelemben a társadalmi integrációnak még mindig több értelmezése lehet. Bosswick és Heckmann (2006) szerint egyszerre jelentheti a következöket:

Azt a folyamatot, amely különbözö elemeket kapcsol össze, ezekböl összeállítva egy új struktúrát. Egyes elemek hozzáadását egy már meglévő struktúrához, hogy egy összekapcsolt egészet hozzunk létre,

Egy meglévö struktúrán belüli kapcsolatok fenntartását vagy fejlesztését.

Az elemek alatt akár egyes embereket, akár embercsoportokat a struktúra alatt pedig ezek össze-kapcsolásából álló egységet értve, úgy kerülhetünk még közelebb a fogalom megértéséhez, ha megkülönböztetjük azt az asszimiláció terminusától. Elöbbi ugyanis egy a befogadó társadalmak és a beérkezők közötti, dinamikus és kölcsönös alkalmazkodási folyamatot jelöl. (Council of the European Union 2004; European Commission 2003:9); Council of Europe 2001:33) Ezzel ellentétben az asszimiláció a kisebbségnek a többség felé történő egyoldalú adaptációját jelenti. (de Palo és tsai, 2006) Az asszimiláció fogalma máig használt például az Egyesült Államokban. (Alba-Nee 2003) az Európai Unió azonban egyértelmüen az integráció által kínált keretekben gondolkodik és cselekszik. (European Commission 2003; Council of Europe 2001; OECD/European Union 2015) Tanulmányunk az 
Európai Unióban használatos fogalmi keretből indul ki, és annak gyakorlati oldaláról megközelítve azt, a társadalmi integráció folyamatainak mérésére koncentrál. A következőkben azt vizsgáljuk, milyen módszertannal történik az alapjaiban egységes, de tagállamonként különböző integrációs folyamatok eredményeinek mérése.

\section{A Közös Alapelvek és a szakpolitikák nemzetközi osztályozása}

Az társadalmi integrációs folyamatok mérésére való igény megszületéséig, előbb magukat a különböző integrációs elképzeléseket kellett közös nevező alá rendezni és törvényben rögzíteni. Az Európai Unió számos olyan törvényt hozott, amely segíti a harmadik országbeliek integrációját (OECD/European Union 2015:300; Rudinger-Spencer 2003:10; Thym 2016). Mindemellett az EU Közös Alapelveket alakított ki a bevándorlók integrációjára vonatkozóan. (Council of the European Union 2004; European Commission 2011; Gilardoni et al 2015:32; OECD/European Union 2015:300) Ezek a minden tagállamra érvényes, 1995ben megalapozott, 2004-ben elfogadott, majd 2014-ben megerősített alapvetések képezik az általános keretét az Unió társadalmi integrációs törekvéseinek. A Közös Alapelvek többek között olyan konkrét törekvéseket tartalmaznak, mint a bevándorlók számára egyenlö hozzáférés és egyenlő jogok biztosítása a munkához, oktatáshoz, különböző intézményi szolgáltatásokhoz, egyéb általános javakhoz és szolgáltatásokhoz, valamint átlátható mérési mechanizmusok kialakítása. A tagállami szakpolitikák és integrációs stratégiák, noha a Közös Alapelvek alapján kialakítottak, részben mégis különbözőek lehetnek irányultságaikban és intézkedéseikben. A tagállamok helyenként eltérő társadalmi integrációs eszközkészletének összevetésére létezik egy nemzetközi módszer, amely a különböző típusú tagállami integrációs politikákat meghatározott szempontok szerint osztályozza. Ezt a módszert a Migrant Integration Policy Index (MIPEX) kínálja. A MIPEX értékelései a harmadik országból érkezők integrálásának lehetőségére, és az annak valószínüségét befolyásoló szakpolitikai intézkedésekre vonatkoznak (Bijl 2008)

A közös irányelvek, tagállami különbözőségek, és ezek osztályozási módjának ismerete mind hasznos ugyan a témánk tárgyalásához, de a tanulmány lényegi célja az előbbieknél valami sokkal kézzelfoghatóbbra, a tagállamokban élő harmadik országbeli bevándorlók társadalmi integráció-jának, mint folyamatnak a mérésére irányul. Ezért foglalkozunk az alábbiakban részletesen a Zaragoza indikátorokkal.

\section{Az integrációs folyamatok eredményeinek mérése}

A Zaragoza indikátorokat, mint a Közös Alapvetéseknek megfelelően kivitelezett tagállami integrációs politikák eredményeinek mérésére szolgáló mutatókat, 2010-ben a Spanyol EU elnökség idején mutatták be. Az indikátorokat egy korábbi, I3 (Indicators of Immigrant Integration) néven elhíresült projektet, nagyszabású, nemzetközi szakértői találkozókat és a Stockholm Program elindulását követően hozták létre. (Bijl 2008; OECD/European Union 2015:300) Az I3 kimondottan a társadalmi integráció mérhetőségével foglalkozott a Stockholm Program pedig a lényegi keretét jelentette a következő ügyekben való közös cselekvéseknek a 2010-2014 közötti időszakban: állampolgárság, igazságszolgáltatás, biztonság, menekültügy, bevándorlás és vízumpolitika. Az indikátorok megalkotásának célja, az volt, hogy mérhetővé váljanak az EU tagállamok társadalmi integrációban mutatott eredményei. A Zaragoza indikátorok a munkapiac, az oktatás, a társadalmi befogadás és az állampolgári aktivitás területein igyekeznek követni a bevándorlók társadalmi integrációját, és szervesen kapcsolódnak az EU 2020 stratégiához. A kapcsolódás alapja az a törekvés, hogy az EU-ban élő 20-64 évesek foglalkoztatási rátáját a 2010-ben mért 64\%-ról 2020-ra 75\%-ra növeljék. Ezt többek között a bevándorlók sikeresebb munkaerőpiacra történő integrálásával érhető el, ami egyben alapja a társadalmi integrációnak is. Eddig egy Eurostat által (Indicators of Immigrant Integration - A Pilot Study) és két az Európai Bizottság által kiadott kötet jelent 
meg 2013-ban (Using EU Indicators of Immigrant Integration) és 2015-ben (Indicators of Immigrant integration), amelyek a Zaragoza indikátorok szükségességét, kialakításuk megfontolásait, és aktuális eredményeiket tárgyalják a 28 EU tagországra vonatkoztatva. A kötetek mind elérhetőek online és jelen tanulmányunk meghatározó forrásai. Az Európai Bizottság által kiadott két kötet némileg különbözik egymástól, egyrészt azért, mert a korábbi kimondottan a Zaragoza indikátorokról szól, a későbbi viszont inkább az EU-n belüli országok között vándorlókkal foglalkozik, és mindössze egy kiegészítő fejezetet szán az Indikátorok tárgyalására. Másrészt a második kötetben megjelölt indikátorok közül jó néhány nem jelenik meg a 2015-ös, legfrissebb, adatokat szolgáltató kiadványban, ami így összességében kevesebb mutatót és kevesebb hozzájuk tartozó statisztikai adatot tartalmaz. (European Commission 2013; OECD/European Union 2015) A különbségek mögött az adatok összehasonlíthatósága, illetve a széles körben elérhető tagállami adatok limitáltsága állhat. A 2015-ös kötetben általában a 28 tagországra vonatkozó, rendelkezésre álló adatok szerepelnek. A továbbiakban Zaragoza indikátorok alatt azok utóbbi, szükített egységét, és a hozzájuk tartozó adatokat értjük. Az egyértelmüsítést követően érdemes rátérni a mérőeszköz felépítésére: A Zaragoza indikátorok összesen tizenhárom különböző, az elöbbiekben bemutatott négy területhez (foglalkoztatás, oktatás, társadalmi befogadás, állampolgári aktivitás) kapcsolódó mutatóból állnak (2. ábra). Az indikátorokat egyrészt Eurostat statisztikák, másrészt több EU survey eredményei alapján töltik fel értékekkel. A felhasznált survey adatfelvételek között szerepel többek között az EU Munka Erő Felmérés (EU Labour Force Survey) az EU Jövedelem és Életkörülmények Felmérés (EU Survey on Income and Living Conditions) és a PISA felmérés (OECD Programme for International Student Assessment) is.

2. ábra: A Zaragoza indikátorok az Indicators of Immigrant Integration (2015) szerinti, tematikus bontásban
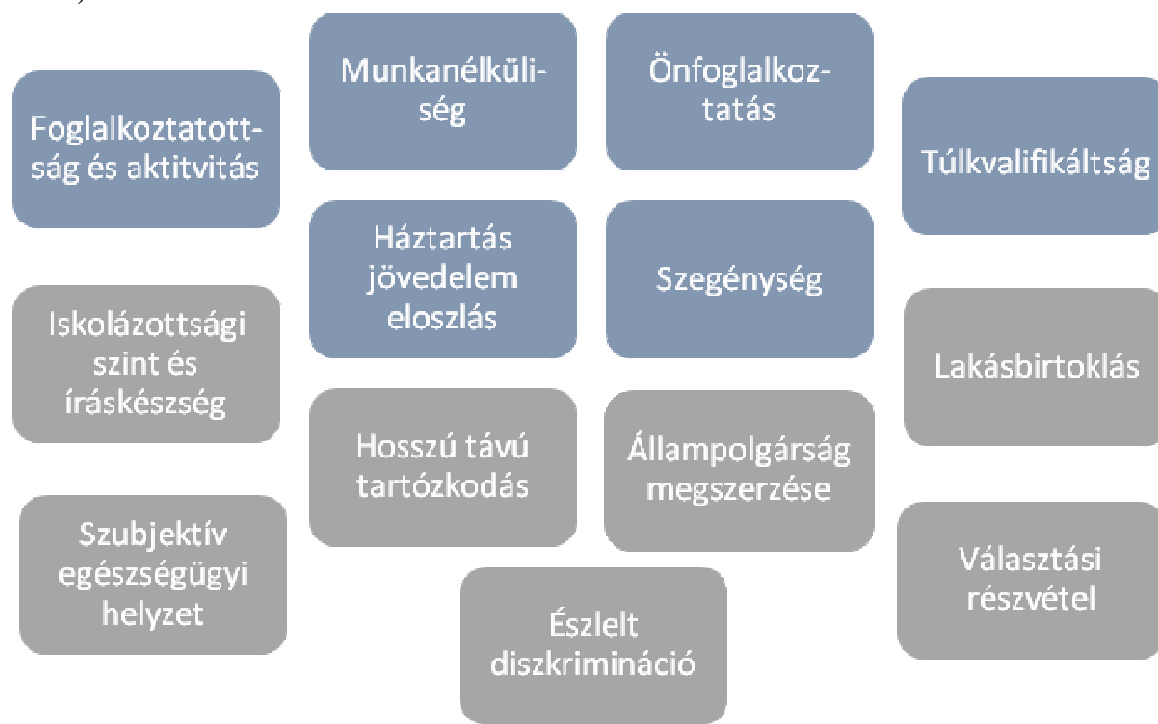

Háztartás

jövedelem

eloszlás

Hosszú táví

Allampolgárság

negszerzése

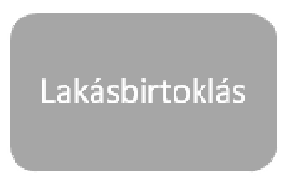

Választási

részzétel

A kutatómunka ezen pontján a tanulmány elsődleges kérdésére („Hogyan mérhető a társadalmi integráció?") az indikátorok fellelésével lényegében választ nyertünk, és az eszközt, amivel a társadalmi integráció elviekben mérhető, megtaláltuk. Ami azonban a mutatók részletes tanulmányozásával feltünt, az magával hozott egy a bevezetésben tárgyalt fő kérdőjel helyére illeszkedő másik kérdőjelet, és egy egészen új irányt adott a kutatómunkának. 
A gazdasági-munkaeröpiaci mutatók túlsúlya

Az indikátorokat vizsgálva feltünik, hogy a gazdasági-munkapiaci kategóriába sorolható mutatók (foglalkoztatottság és aktivitás; munkanélküliség; önfoglalkoztatás; háztartás jövedelem eloszlás; szegénység; lakásbirtoklás) száma túlsúlyban van az oktatás, társadalmi befogadás, állampolgári aktivitás kategóriáiba tartozó mutatókkal szemben, mivel a 13 mutató majdnem fele gazdasági vonatkozású. Ez önmagában még nem jelentene gondot, hiszen az EU szerint a társadalmi integráció alapvető feltétele, a bevándorlók munkaerőpiaci integrációja (Council of the European Union 2004). Mégis, talán feltételezhetjük, hogy a többi hét, páronként vagy egyenként különböző aspektusokat bemutató indikátorral kiegészülve, a tizenhárom, a társadalmi integráció folyamatának mérésére használt mutatószámcsoport csak részlegesen képes betölteni a hozzá füzött reményeket. Az iskolai teljesítmény, a szubjektív egészségügyi helyzet, a hosszú távon a tagállamokban tartózkodók aránya, és az állampolgárság megszerzésének nehézsége önmagában nem sokat árul el a natív lakosság és a bevándorlók viszonyáról, vélekedéseikről és a társadalmi integráció napi interakciók szintjén érzékelhető folyamatairól. Ezt ellensúlyozandó ugyan jelen van egy az észlelt diszkrimináció mértékét jelző mutató, azonban ez egyrészt egyoldalúan, csak bevándorlók nézőpontjából vizsgálja az együttélés kérdéseit, másrészt a további, hasonló mutatók hiányát nehezen képes ellensúlyozni. A társadalmi integráció teljesebb méréséhez az előbbieket figyelembe véve véleményem szerint szükség lenne olyan mérőszámokra, amelyek megmutatják a bevándorlók és a befogadó országok „natív társadalma” közötti távolságot (Bogardus, 1925), a tagországokban meglévő idegenellenesség (Simonovits-Szalai, 2013) és a jelenlévő összekötő társadalmi tőke (Statham-Tillie, 2016:181; Durlauf 2002) mértékét. A kutatómunka következő lépését ezután ennek megfelelően olyan már meglévő kutatások keresése jelentette, amik pótolhatják a Zaragoza indikátorok hiányosságait. Az abszolút találatot pedig az EurIslam nevü kutatási projekt jelentette.

\section{Az EurIslam kutatás}

Az EurIslam kutatás az Európai Bizottság 7. keretprogramjának egyik kutatási projektjeként azt vizsgálta, hogyan alakul a muszlim és más bevándorló csoportok integrációja az állam és egyház viszonyának, a nemzeti identitásnak, valamint állampolgárság megélésének a kérdéseire helyenként eltérő válaszokkal és hagyományokkal rendelkező európai országokban. Ebben a kutatásban megjelenik az összes korábban hiányolt mutató, ráadásul rávilágít egy újabb fontos tényre, amit véleményem szerint figyelembe kell vennünk, ha harmadik országból érkező bevándorlók európai országokba történő integrálásáról és integrálódásáról van szó. Ez pedig a kulturális dimenzió. Ebben a szinte meghatározhatatlan fogalomban való elmélyülés most messzire vezetne a tanulmány eredeti céljától ezért csak azt jelzem, hogy jelen esetben a kultúra milyen formában meghatározott jelentésére támaszkodom. A fogalmat itt a kultúrakutatás területén véghezvitt kutatómunkájuknak köszönhetően legendásnak számító szerzőpáros, Kroeber és Kulckhohn elgondolásai szerint szeretném használni: Szerintük a kultúra közvetett vagy közvetlen viselkedésmintákból álló rendszer, amely szimbólumok által közvetített, lényege tradicionális gondolatokból, ideákból és értékekböl épül fel, és egyrészt korábbi cselekvések terméke, másrészt jövőbeli cselekedetek feltételrendszere. (Kroeber - Kulckhohn, 1953:157) Ha a kultúra kifejezést ilyen értelemben használjuk, akkor erősödhet bennünk a hiányérzet a Zaragoza indikátorokat illetően. A társadalmi integrációnak ugyanis egy kulturális dimenziója is értelmezhető, amit az EurIslam kutatói a kezdetektől szem előtt tartottak (Koomen és tsai, 2012:10; Statham Tillie, 2016; Penninx, 2004).

E rövid kitérő után térjünk rá az EurIslam kutatás aktualitásának tárgyalására. Az elmúlt két évtizedben az Iszlám vált ugyanis a határok meghúzásának fő eszközévé a többségi 
társadalmak és a bevándorlók között egész Európában. Az európai viták, amik a multikulturalizmus előnyeit, és hátrányait boncolgatják, szintén közvetlenül az iszlámnak az európai hagyományoktól való különbözőségét emelik ki. Ilyen jellegü különbségtételek rezonálnak Európa-szerte többek között a tagállami tömegmédiákban (Koomen és tsai, 2012:9; Statham - Tillie, 2016)

Egyértelmű érdeklődés övezi tehát a kulturális különbségeket, ennek megfelelően az EurIslam kutatói főként a muszlim bevándorlók nyugat-európai társadalmakba történő társadalmi-kulturális integrációjára fókuszáltak. A projektben hat európai országot vizsgáltak, amelyek a legnagyobb számban muszlim bevándorlókat befogadó országok voltak a 80-as évekig. Az érintett országok a befogadott muszlimok aránya szerinti csökkenő sorrendben: Franciaország; Németország; Nagy-Britannia; Hollandia; Belgium; és Svájc. Ez a hat ország adja a Zaragoza indikátorokkal való kapcsolódás lehetőségét, amelyet kihasználva, a tanulmány következő szakaszában egy empirikus kísérletet teszünk az EurIslam által érintett hat ország Zaragoza indikátorokkal történő vizsgálatára, és a kapott eredmények egymáshoz illesztésére. Elötte azonban még utalunk egy fontos jellemzőre, amivel, amivel az EurIslam hozzájárul a társadalmi integráció méréséről alkotott eddigi képünk árnyalásához.

A felsorolt országok azért is érdekesek, mert mindegyikük megtapasztalt már, háború utáni bevándorló-beáramlást, de némileg eltérő módokon kezelték és kezelik a migránsok és kisebbségek helyzetét és az EurIslam megalapozásai szerint elkülöníthető integrációs stratégiákkal rendelkeznek. Ezek a különbségek jól dokumentáltak, ma is megfigyelhetők, és több csoportba sorolhatók, amelyek némelyikét az országok egyedül, némelyikét párban képviselik (Statham-Tillie, 2016:179). Az elkülöníthető csoportok és rövid leírásaik a következők:

\section{Egyesült Királyság és Hollandia}

A britek és a hollandok egyfajta multikulturalista hozzáállással rendelkeznek a bevándorlók integrálásának kérdését illetően. Ez a megközelítés elősegíti a bevándorló csoportok etnikai alapon történő szerveződését és intézményesülését. A hollandokhoz viszonyítva a britek hagyományosan inkább a társadalmi-gazdasági lehetőségek egyenlősége mellett elkötelezettek és kevésbé hangsúlyosnak tekintik a kulturális kérdéseket. Ezek a különbözö megközelítések ráadásul különböző egyház-állam berendezkedéssel járnak együtt a két országban. A briteknél az Anglikán Egyház különböző előnyöket élvez, és szorosabb kapcsolatban áll az állammal, míg a hollandoknál egyértelmü a vallási pluralizmus. A tapasztalható különbségek ellenére a hasonlóságok kiemelésével az EurIslam kutatásban egy adott csoportba sorolták a két országot (Statham - Tillie, 2016:180).

\section{Németország és Svájc}

A németeknek és a svájciaknak hosszú ideig erőteljes, etnikai alapú elképzeléseik voltak a nemzet fogalmáról. Ennek megfelelően a bevándorlóknak relatíve nehezebb volt ezekben az országokban egyenlő jogokat szerezniük. Az EurIslam kutatói szerint, a német és svájci elképzelések sokáig csak „munkás kezeket” láttak a migránsokban, és az integráció is elsősorban a munkaerőpiacra fókuszált. Az egyezések ellenére a két országban az állam és a vallási intézmények közti interakció eltérően alakul. Svájcban jobban különvált az állam és az egyház, Németországban viszont kimondottan zsidó és keresztény hagyományokra építkeztek (Statham - Tillie, 2016:180).

\section{Franciaország}

A franciáknak a köztársaság alapjaihoz való hüségét az integrációs elképzeléseik is tükrözik. Az általuk képviselt társadalmi integrációs séma a következőképpen foglalható össze röviden: „A bevándorlóknak, mint egyéneknek egyszerü hozzáférést az egyenlö 
jogokhoz, de mindezt a csoport különbségek felismerésének és kezelésének elkerülésével”. Franciaország leginkább a társadalmi-gazdasági egyenlőség biztosításával próbálta és próbálja előidézni a társadalmi-kulturális integráció létrejöttét (Statham - Tillie, 2016:180).

\section{Belgium}

A belgák különösen érdekes esetként, két külön említhető sémát dolgoztak ki. Északon egy multikulturalistább, ún. „pillarizált”, a hollandokéhoz hasonlító szemléletmóddal élnek, míg délen a franciákéhoz hasonló integrációs törekvéseket valósítottak meg (Statham - Tillie, 2016:180).

A fentiek persze a csoportok egyszerüsített, tömör leírását adják. Ahhoz, hogy alaposabban megérthessük a közöttük lévő különbségeket egy hosszabb terjedelmü, más fókuszponttal rendelkező írásra lenne szükség, a most következö kísérlethez azonban a fenti információk bőven elegendőek. Hozzá kell tenni továbbá, hogy a felsorolt jellemzők nem kőbevésettek, és idővel változhatnak. Kiváló példa erre, ami a németeknél történt, ahol 2000-től minden Németországban született gyermek automatikusan német állampolgárnak számít. Következzen tehát a már többször említett kísérlet leírása.

\section{Kísérlet hat ország egymáshoz viszonyított értékelésére a Zaragoza indikátorok és az EurIslam eredményeinek segítségével.}

A tanulmány következő részében megkíséreljük annak bizonyítását, hogy bár a Zaragoza indikátorok jelenlegi formájukban is szükséges, de egyelőre nem elégséges feltételei a társadalmi integráció pontos mérésének, mivel nem képesek a társadalmi integrációs folyamatok kulturális dimenzióját lefedni. Ehhez, a Zaragoza indikátorok és az EurIslam kutatás által egyaránt érintett hat ország adatait elemezzük. Az EurIslam adatok és Zaragoza indikátorok kombinált segítségével előbb az indikátorok szerint hasonlítjuk egymáshoz a hat országot, és állítunk fel végeredményben egy sorrendet közöttük, majd összevetjük az így kapott országok Zaragoza- teljesítményét az EurIslam kutatás vonatkozó eredményeivel. Persze klasszikus értelemben lehetetlen itt összehasonlítást eszközölni, hiszen a Zaragoza indikátorok több különböző kutatás és adatforrás felhasználásával összeállított komplex egységet alkotnak, az EurIslam pedig egyetlen specifikus kutatás, ráadásul mindketten mást is mérnek. A különböző típusú adatok ugyanakkor ugyanazon adott országokban élő bevándorlókra és a többségi társadalmak tagjaira vonatkoznak, így kvázi kiegészítik egymást. Mindemellett, ha elgondolásaim helyesek, könnyen előfordulhat, hogy az egymáshoz viszonyított Zaragoza teljesítmények, és ezeknek az EurIslam szerinti kiegészítései között az olvasó számára is világos diszharmónia alakulhat ki.

\section{Az összehasonlítás módszere}

Az összehasonlítás egyik alapját tehát a vizsgált hat tagállam (Egyesült Királyság; Hollandia; Németország; Svájc; Franciaország; Belgium) Zaragoza eredményei adják. A korábbiakban felsorolt indikátorok értékei a legtöbb esetben tagállamonként a harmadik országból érkező bevándorlók csoportjára és a natív lakosságra külön meghatározottak. Ezek közül korábban minden alkalommal kiválasztottuk a vizsgált hat tagállamra vonatkozó eredményeket, majd egyszerüen elosztva a harmadik országbeli bevándorlók csoportjainak értékeit a natív lakosságéval, tagállamonként egy-egy hányadost kaptunk eredményül. Ezek a hányadosok 0 és 1 közötti valós számok, amik egyenként, az aktuálisan vizsgált mutatók értelmében a bevándorlók helyzetét hasonlítják a többségi társadaloméhoz. Minél közelebb van a hányados az 1-hez, annál kevesebb különbség van a két csoport értékei között, így az indikátor által mért tényező tekintetében annál eredményesebben integrál az adott tagország. Az előzőek szerint képzett számokat országonként összehasonlítva, mutatónként kialakult 
egy-egy sorrend, aminek megfelelően pontozásra került az országok teljesítménye. A legjobban teljesítő ország hat pontot, a második öt pontot kapott, és így tovább, egészen az utolsó, egy pontot érő teljesítményig. Ha egy országra az éppen tárgyalt indikátor nem tartalmazott megjeleníthető adatot, úgy azt az összehasonlítás végén, azt az adott ország addigi eredményeinek átlagából képzett pontszámmal helyettesítettük, a kapott pontszámok összeadásával pedig kialakult az 1. táblázatban látható végeredmény.

\section{Az összesített Zaragoza eredmények és a kapcsolódó EurIslam kiegészítések}

Az összesített eredmények alapján a hat ország közül első helyen végzett az Egyesült Királyság a „mezőny” előtt jókora fölénnyel, összességében pedig a hatos skálán 5,25-os átlagpontszámmal (1. táblázat). A társadalmi integráció folyamatában tehát a Zaragoza indikátorok szerint mérve az Egyesült Királyság példaértékü eredményekkel rendelkezik.

$\mathrm{Az}$ összehasonlítás végeredményben ugyan csoportszinten is az Egyesült Királyság és Hollandia zárt az első helyen. Ha az országokat egyenként vizsgáljuk, akkor viszont kiderül, hogy a más integrációs stratégiával rendelkező Németország megelőzte Hollandiát, és úgy tünik azok a csoportok, amelyeket két ország képvisel, az eltérő egyéni eredmények alapján felbonthatók.

1. táblázat: Az egyes tagállamok összesitett Zaragoza eredményei és a kialakult sorrend.

\begin{tabular}{|l|c|c|c|}
\hline \multicolumn{1}{|c|}{ Ország } & Pontszám & Átlag & Helyezés \\
\hline Egyesült Királyság & 63 & 5,25 & 1. \\
\hline Németország & 50 & 4,19 & 2. \\
\hline Hollandia & 40,5 & 3,38 & 3. \\
\hline Svájc & 40 & 3,33 & 4. \\
\hline Franciaország & 37 & 3,08 & 5. \\
\hline Belgium & 36 & 3,00 & 6. \\
\hline
\end{tabular}

Az EurIslam eredményeit is figyelembe véve azonban egy diszharmonikus kép kezd előttünk kirajzolódni, ugyanis:

- A befogadó országgal való identifikálódás szintje az Egyesült Királyságban, és Németországban élő muszlim bevándorlók között a legalacsonyabb. (Koomen és tsai, 2012:93)

- Az Egyesült Királyságban, Hollandiában és Németországban a muszlimok kevésbé érzik magukat elfogadva, mint Franciaországban. A három ország közül az Egyesült Királyságban érzik magukat a legkevésbé elfogadva (Koomen és tsai, 2012:94).

- Az Egyesült Királyságban, Belgiumban, Hollandiában, Németországban és Svájcban is alacsonyabb a bevándorlók elfogadottságának szintje, mint Franciaországban. A felsoroltak közül a legkevésbé elfogadó natív társadalom az Egyesült Királyságé. (Koomen és tsai, 2012:95)

- A különböző bevándorló csoportok és a többségi társadalom közötti észlelt távolság mértéke a legkisebb Franciaországban, a legnagyobb az Egyesült Királyságban. Az Egyesült Királyság után az észlelt távolságok szerinti csökkenő sorrend: Hollandia, Belgium, Németország, Svájc (Koomen és tsai, 2012:96).

- Az EurIslam kutatói szerint az összekötő társadalmi tőke tekintetében a legjobban Belgium áll, utána Hollandia, Németország, majd Svájc következik a sorban. Az Egyesült Királyság ebben az összehasonlításban az utolsó helyen áll (Koomen és tsai, 2012:98). 
Az összeillesztett eredményekből kirajzolódó egész tehát meglehetősen zavaros. Ennek az értelmezése és a lehetséges okok, torzítások figyelembevétele a következő lépés, amit meg kell tennünk. Az első lehetséges vizsgálati szempont itt a korábban már tárgyalt megbízhatóság, a mintavételeket, és kérdéseket tekintve azonban mind a két adatforrás makulátlannak tünik. A második szempont lehet az érvényesség, amiben már találhatunk a különbségeket magyarázó okot. Az előbb felsorolt kiegészítések nagy része ugyanis nem általában a bevándorlókra, hanem a muszlim bevándorlókra vonatkozik. Ezt azonban az összehasonlítás kezdetétől fogva tudjuk és ettől függetlenül az, hogy a két forrásból származó képkockák ennyire különböző képet mutatnak, csökkenti az esélyeit annak, hogy pusztán ez az ok állna a háttérben. Ha feltételezzük, hogy az illesztett kép alapját jelentő kutatások módszertanilag teljesen megfelelőek, az eredmények helytállóak, és ugyanazokra az országokra vonatkoznak, mindössze a társadalmi integráció más-más aspektusait mérik, akkor jogosan élhetünk a feltételezéssel, hogy a kapott eredmények a Zaragoza indikátorok hiányosságaira világítanak rá.

\section{Konklúzió}

E tanulmányban annak a 2015-ös migrációs válság hosszutávú hatásairól való gondolkodás során keletkezett kérdésnek jártunk utána, hogy: Hogyan mérhetö a társadalmi integráció? Áttekintettük a migrációs válság Eurostat adatokkal történő értelmezését, az integráció elméleti-fogalmi megfontolásait, az Európai Unióban használt mérési módszerek bemutatását és az azok vizsgálatával felfedezett néhány hiányosságot. Mindent egybevetve úgy tünik, hogy az EurIslam kutatások több értelemben véve (országok és bevándorló csoportok szerint) is kiterjesztett folytatására, és a Zaragoza indikátorok frissülö értékeivel együtt történő értelmezésére lenne szükség az elkövetkezendő években. Az EurIslam több olyan, a társadalmi integráció kulturális dimenziójához, valamint a bevándorlók és a többségi, befogadó társadalmak mindennapi együttélési folyamataihoz tartozó mutatóval rendelkezik, amelyeknek a Zaragoza indikátorok közé való beemelése megfontolandó. Az indikátorok ilyenfajta kiegészülése nagyszerü lehetőségeket adna a társadalmi integráció európai tagállami szintü és egységes folyamatának a minél teljesebb megértéséhez, hibáinak és hiányosságainak feltárásához, és a migrációs válságnak a bevezetésben említett, jövőben jelentkező, hosszabb távon megmutatkozó hatásainak az elörejelzéséhez, és monitorozásához.

\section{Irodalom}

Alba, R. - Nee, V. (2003): Remaking the American Mainstream - Assimilation and Contemporary Immigration. Cambridge, MA: Harvard University Press,

Bijl, R. (2008): Evaluating the social integration of immigrants: how to measure successes and failures? - The Netherlands Isntitute for Social Research (Letöltés: 2016.07.10. Web: http://www.gesis.org/fileadmin/upload/dienstleistung/veranstaltungen_fortbildungen/archiv /soz_ind/Villa_Vigoni/Bijl_integration.pdf).

Bocz, J. (2002): Társadalmi Integráció?! De ez mit jelent?! A Magyar Szociológiai Társaság konferenciáján elhangzott előadás, Szeged December 12-13. (Letöltés: 2016.07.10. Web: http://www.socialnetwork.hu/cikkek/bocz2002MSZT.htm).

Bogardus, E. S. (1925). Measuring Social Distances. Journal of Applied Sociology, 1-2, 299308.

Bosswick, W. - Heckmann, F. (2006): Social integration of immigrants: Contribution of local and regional authorities. Brussels, European Foundation for the Improvement of Living and Working Conditions (Letöltés: 2016.07.10. Web: http://edz.bib.unimannheim.de/daten/edz-ma/esl/06/ef0622en.pdf). 
Bourdieu P. (1994): A gyakorlati észjárás - a társadalmi cselekvés elméletéröl. Budapest, (Napvilág Kiadó 2002)

Castells, M. (1996). The Rise of the Network Society, The Information Age: Economy, Society and Culture Vol. I. Cambridge, UK: Blackwell

Council of Europe (2001): Measurement and indicators of integration Strasbourg, Council of Europe Publishing (Letöltés: 2016.07.10. Web: http://www.coe.int/t/dg3/migration/archives/documentation/Series_Community_Relations/ Measurement_indicators_integration_en.pdf).

Council of the European Union (2004): Press Release - 2618th Council Meeting - Justice and Home Affairs. Brussels: Council of the European Union

Council of the European Union (2009): The Stockholm Programme-An open and secure Europe serving and protecting the citizen. (Letöltés: 2016.07.10. Web: https://ec.europa.eu/anti-trafficking/sites/antitrafficking/files/the_stockholm_programme__an_open_and_secure_europe_en_1.pdf).

de Palo, D., Faini, R., Venturini, A. (2006): The Social Assimilation of Immigrants. Bonn: IZA (Letöltés: 2016.07.10. Web: http://ftp.iza.org/dp2439.pdf ).

Drost, E. A. (2011): Validity and reliability in social science research. Education and research perspectives, 38(1): 105-123.

Durkheim, E. (1951): Suicide: A study in sociology. Glencoe, IL: Free Press

Durlauf, S. N. (2002): On the empirics of social capital. The Economic Journal, 112: 459-479.

Babbie, E. (2003): A társadalomtudományi kutatás gyakorlata. Budapest: Balassi Kiadó

European Commission (2003): Migration and Social Integration of Migrants - Valorisation of research on migration and immigration funded under 4th and 5th European Framework Programmes of Research Brussels: European Commission (Letöltés: 2016.07.10. Web: https://cordis.europa.eu/pub/citizens/docs/migration_report.pdf).

European Commission (2011): Communication from the Commission to the European Parliment, the Council; the European Economic and Social Committee and the Comittee of the Regions - European Agenda for the Integration of Third-Country Nationals. Brussels: European Commission (Letöltés: 2016.07.10. Web: http://ec.europa.eu/dgs/homeaffairs/news/intro/docs/110720/1_en_act_part1_v10.pdf).

European Commission (2013): Using EU Indicators of Immigrant Integration. Brussels: European Commission (Letöltés: 2016.07.10. Web: https://ec.europa.eu/migrantintegration/index.cfm?action=media.download\&uuid=FC375682-95DF-1B86CF670D84CA41C2D6).

European Migration Network EMN (2014): EMN Annual Report on Immigration and Asylum 2014. Brussels: European Commission (Letöltés: 2016.07.10. Web:

http://emn.ie/files/p_201506160344022014emn_annual_report_on_immigration_and_asylu m.pdf).

Gilardoni, G., D'Odorico, M., Carrillo, D. (2015): KING Knowledge for INtegration Governance - Evidence on migrants' integration in Europe. Milan: Fondazione ISMU (Letöltés: 2016.07.10. Web: http://king.ismu.org/wp-content/uploads/KING_Report.pdf).

Jean, T., Maarten, K., Van Heelsum, A., Damstra, A. (2012) : EurIslam Final Integrated Report (Letöltés: 2016.07.10. Web: http://www.eurislam.eu/var/EURISLAM_Final_Integrated_Research_Report_1.pdf). Juhász József (1989): Magyar Értelmezö Kéziszótár. Budapest: Akadémia Kiadó Vol. 1, pp. 223

Kovách, I., Dupcsik, Cs., P.Tóth, T., Takács, J. (2012): Társadalmi integráció a jelenkori Magyarországon. Budapest: Argumentum Kiadó. Vol. 1, pp. 7-17

Mouzelis, N. (1992): Social and System Integration: Habermas' View. The British Journal of Sociology 43.2 267-88. 
OECD/European Union (2015): Indicators of Immigrant Integration 2015: Settling In. Paris, OECD Publishing (Letöltés: 2016.07.10. Web: http://dx.doi.org/10.1787/9789264234024en).

Penninx, R. (2004): Integration of Migrants: economic, social, cultural and political dimensions. Background Paper for the UNECE-conference January 12-14, 2004, Geneva (Letöltés: 2016.07.10. Web:

http://www.unece.org/fileadmin/DAM/pau/_docs/pau/2004/PAU_2004_EPF_BgDocPenni nx.pdf).

Rudinger, A., Spencer, S. (2003): Social Integration of Migrants and Ethnic Minorities Policies to Combat Discrimination. Brussels, European Commission- OECD (Letöltés: 2016.07.10. Web: http://www.oecd.org/migration/mig/15516956.pdf).

Simonovits, B., Szalai, B. (2013): Idegenellenesség és diszkrimináció a mai Magyarországon. Magyar Tudomány, 2013: 3, 251-262.

Statham, P., Tillie, J. (2016): Muslims in their European societies of settlement: a comparative agenda for empirical research on socio-cultural integration across countries and groups In: Journal of Ethnic and Migration Studies, 42:2, 177-196.

Thym, D. (2016): Towards a Contextual Conception of Social Integration in EU Immigration Law - Comments on P \& S and K \& A European Journal of Migration and Law 89-111

Weber, M. (1995): Gazdaság és társadalom: A megértố szociológia alapvonalai 1. Budapest: Közgazdasági és Jogi Kiadó 